\title{
AN INVENTORY DATABASE FOR GEOEDUCATIONAL OUTREACH BASED ON VOLUNTEERED GEOGRAPHIC INFORMATION (VGI) APPROACH IN MALAYSIA
}

\begin{abstract}
Norbert SIMON*
University Kebangsaan Malaysia, Center for Earth Sciences and the Environment, Faculty of Science \& Technology, University KebangsaanMalaysia, 43600 Bangi, Selangor; Institute for Environment and Development (LESTARI), 4360o Bangi, Selangor, Malaysia, e-mail: norbsn@ukm.edu.my
\end{abstract}

\section{Che Aziz ALI}

University Kebangsaan Malaysia, Geology Program, Faculty of Science \& Technology, 43600 Bangi, Selangor, Malaysia, e-mail: che@ukm.edu.my

\section{Marilah SARMAN}

University Kebangsaan Malaysia, Geology Program, Faculty of Science \& Technology, 43600 Bangi, Selangor, Malaysia, e-mail: marilah@ukm.edu.my

\section{Dana BADANG}

Department of Minerals and Geoscience Malaysia, Level 8 \& 9, PJH Tower, No. 2, Tun Abdul Razak Road, Precinct 2, 62100 Putrajaya, Malaysia, e-mail: dana@jmg.gov.my

\section{Tanot UNJAH}

University Kebangsaan Malaysia, Institute for Environment \& Development (LESTARI), 4360o Bangi, Selangor, Malaysia, e-mail: tanot-u@ukm.edu.my

\section{Mat Niza RAHMAN}

Department of Minerals and Geoscience Malaysia, Level 8 \& 9, PJH Tower, No. 2, Tun Abdul Razak Road, Precinct 2, 62100 Putrajaya, Malaysia, e-mail: mniza@jmg.gov.my

Citation: Simon, N., Ali, C. A., Sarman, M., Badang, D., Unjah, T., \& Rahman M. N. (2018). AN INVENTORY DATABASE FOR GEOEDUCATIONAL OUTREACH BASED ON VOLUNTEERED GEOGRAPHIC INFORMATION (VGI) APPROACH IN MALAYSIA. GeoJournal of Tourism and Geosites. 23(3), 684-701. https://doi.org/10.30892/gtg.23306-320

\begin{abstract}
The authors aim to construct a geosite database in Malaysia that is based on volunteered geographic information approach. This is because geosites information is quite scattered around the country. Free tools from the internet such as google form and wixwebsite.com were used to produce the database. The database is used to compile information not just from researchers but also from the public, and also functions to store, display and promote geosites in Malaysia. Therefore, based on its current functionality, this database could also perform as geo-educational tool for the public and also in an effort to conserve area with high geological interest.
\end{abstract}

Key words: Database, geosite, geoheritage, inventory, volunteered geographic information

\footnotetext{
* Corresponding author
} 
An Inventory Database for Geoeducational Outreach Based on Volunteered Geographic Information (VGI) Approach in Malaysia

\section{INTRODUCTION}

Geodiversity as defined by Dixon (1996) is a range or diversity of features, assemblages, systems and processes in geology, geomorphology, and soil. A geosite on the other hand is defined differently. A definition provided by the European Association for the Conservation of the Geological Heritage (ProGeo) 2011, clearly stated that a geosite is a 'key locality' that shows geological features with scientific interest, which can tell a story on the evolution of the earth and geological history. Such elements are for examples, stratigraphy, palaeobiology, mineral, plate tectonic, volcanic, and so on. A geodiversity therefore is a term used to indicate a group of geosites with different geological featuress in an area. To date, Malaysia has one UNESCO Global Geopark and two national geoparks. The first Geopark in Malaysia is known as the Langkawi UNESCO Global Geopark (LUGG), and the other two geoparks are the Jerai National Geopark and Kinta Valley National Geopark. The LUGG has three geoforest parks namely, the Machinchang Cambrian, Kilim Karst, and Dayang Bunting Marble Geoforest Parks (Ali et al., 2012).

The Machinchang showcases the oldest rock formation in Malaysia (550-490 million years old with abundant fossils and unique landscape. The prominent geosites in the Kilim Karst Geoforest Park are caves (e.g. Kelawar, Buaya, Langsir, etc), Langgun Lake, and Mempelam Bay. The Dayang Bunting Marble Geoforest Park features a large doline which is now has become a lake. This geoforest park features diverse minerals, fossils, and landforms in its many geosites (e.g. Ular Island, Tuba Island, Tepor Island, and Wang Buluh Cave). The Kinta Valley National Geopark is predominantly underlain by limestone formation with small occurrence of other clastic sedimentary rocks and its geosites are mostly on cave formation and fossils (e.g. Gunung Kanthan), hot spring (e.g. Lubuk Timah Hotspring), and waterfall (e.g Batu Berungkai waterfall) (Daud et al., 2017). The Jerai National Geopark covers around $500 \mathrm{~km}^{2}$ and has around 25 geosites that have been identified (Zakaraya, 2017). The few examples of these geosites are found along the footslope of Mount Jerai, and Titi Hayun Recreational Center.

In order to conserve geosites, inventory is the first step to be taken (Moura et al., (2017). Dixon (1996) stated that the greatest obstacle to achieve the objectives of conserving geological sites are the lack of information that provides details on the uniqueness, importance and best representatives of features in a country. Failure to to do so have led to certain geosites being removed or damaged by anthropogenic causes. For example, inundation of Lake Pedder landform assemblages and removal of terminal moraine marking, both by hydroelectric development and quarry respectively (Dixon, 1996). Internationally, many countries have produced programs and wide range of approaches to document the diversity of geological and geomorphological interests in their countries (Dingwall et al., 2005). In Malaysia, systematic and centralised documentations of geosites remains a challenge. One notable paper on a database that can compile and store information on geosite was first published in 2004 (Komoo et al., 2004). The database constructed using Microsoft Access has three sections; general information such as locality, name of geosites, etc; heritage characterisation information; and geosite management information. At past, this database is appropriate as as information of geosites are still few in numbers. However, as development in Malaysia is rapidly progressing, identification of new geosites must be conducted faster than the previous years. This effort must involves not only the government agencies but also the public. Therefore new database system that could be used easily to compile, stored, and display information on geosites is urgently needed to keep up with the pace with the current situation. Apart from getting an up to date system, this study has also identified several reasons on why a database is urgently needed at this moment in Malaysia. Some of the reasons are: 
- geosite mapping and geopark have been one of the national agendas within the past few years and government agencies throughout Malaysia are actively pursuing it;

- national institutions are also conducting many research on potential geosite which connect geology with other disciplines such as biology, ecology, and culture;

- there is also a need to educate the public and make them aware on the existence of geosite throughout the country, this could help in protecting and promoting the geosite. Therefore, as these events are occurring, vast data are pouring in and a system is needed to keep and manage these mass of data. Based on the necessity mentioned above, this study is conducted to focus on four objectives as follows:

a) To produce a system that is capable to capture data through crowdsourcing

b) To design a system that is friendly and familiar to the end user and to the administrator

c) To compile data on potential geosites in the country via one centralised system

d) To design a system that could be used for public education

In Malaysia, the government commitment to develop and maintain the tourism sector is almost limitless, making this sector ranks second in GDP contribution after the manufacturing sector (Mosbah \& Saleh, 2014). Producing the database to document geosites in Malaysia is in line with the vision and mission of Tourism Malaysia to transform the country into a world class tourist destination by the year 2020 and at the same time to conserve the heritage of the country (Ministry of Tourism, Arts, and Culture Malaysia). The term 'heritage' used here could also include natural heritage such as geoheritage, which comprises of geological features high in scientific, cultural, aesthetic and educational significance (Lazzari \& Aloia, 2014; Kepalaite, 2015).

\section{PURPOSES OF A GEOSITE DATABASE}

When dealing with enormous amount of data several questions may arise starting with what information to keep and why? how to keep this data? and where to store them? If these information are for the public (e.g. education), how to get them across? Based on these questions, the literature studies in this article are divided into four parts as follows: Data inventory, record keeping, public involvement, and lastly, how to get the information to the public.

\section{(a) Database inventory for a geosite/geoheritage}

Geological heritage or geoheritage is essentially important because they are an open book that contains the memory of the earth that tells us about events that happened in the past; without them, we would not be able to understand the processes that affected our earth at present (Diaz-Martinez \& Gullen-Mondejar, 2009). At the international level, geoheritage has become important because it has the story that are linked to the history of human civilization providing resources for development and also providing a sense of place not only to the community around the place but also to visitors (Brocx \& Semeniuk, 2009). One of the ways to manage and plan for development and conservation of geoheritage sites is to have a proper inventory system.

The importance of geoheritage inventories is well discussed in Betard et al., (2015), where according to them, an inventory is part of the documentation for decision making in geopark application and also in solving management issues that are related to geotourism and geoconservation. Their inventory, which is done in the Regional Natural Park of France (PNR territory), comprises of 143 geosites that were ranked based on their level of importance that were obtained from numerical assessment conducted during the inventory process. The rank range from low heritage value with local interest (o star) to high heritage value with international interest ( 3 star); within the PNR territory, there are 19 geosites with 
An Inventory Database for Geoeducational Outreach Based on Volunteered Geographic Information (VGI) Approach in Malaysia

3 stars, 34 geosites were given 2 stars, and the other 53 with just 1 star. Ranking these geosites would not be possible without a proper documentation on each of the geosite.

Inventory for geosite/geoheritage is not only useful for geotourism and geoconservation. It also constitutes a good foundation for geoeducation activities (Betard et al., 2015). Vye (2016) has demonstrated on how geosites inventory can play a significant role in educating the public in Keweenaw Peninsula. This is done by stewardship of geosites program. The educational values for these geosites were derived from qualitative assessments done by school teachers. Thus, in view of the benefits to have geosites inventories at the international level, IUGS $(2012,2014)$ has included developing an inventory for geoheritage sites as one of their main objectives that need to be achieved in their Geoheritage Task Group. Several data inventory methodologies have been adopted by various researchers in the past. Brilha (2016) has proposed several inventory elements for a geosite. These elements are arranged in sequential order including scientific, educational and touristic values. Another well demonstrated method of an inventory system can be found in Randrianaly et al., (2016) in which the system is focused more on acquiring elements in the field and the data input requirement are very comprehensive which include the general information on the geological site (e.g. property, toponym, GPS coordinates, geological map, scientific interest, etc) and secondary information such as the type of protection, level or preservation and the existence of cultural values resembling myths or legendary stories. Other method of inventory at the local and regional levels are discussed in depth by Joyce (2010) and Vye (2016).

\section{(b) Record keeping}

One of the prime example of geoheritage database is found in Calder et al., (2017). They have produced a database containing geosites in Nova Scotia that is completed with levels of significance for each geosite. These geoheritage sites were separated into natural and cultural sites. The attributes provided for each category are presented in Table 1.

Table 1 Categories in the Nova Scotia database system (Source: modified from Calder et al. 2017)

\begin{tabular}{|l|l|}
\hline \multicolumn{1}{|c|}{ Natural category } & \multicolumn{1}{c|}{ Cultural category } \\
\hline Site name & Site name \\
\hline County, age (geological period) & $\begin{array}{l}\text { County, category (e.g. First nation sites, } \\
\text { memorials, museums) }\end{array}$ \\
\hline $\begin{array}{l}\text { Level of significance (i.e. 1-globally unique, 2- } \\
\text { globally significant or 3-exceptional example }\end{array}$ & Coordinate information \\
\hline Brief description & $\begin{array}{l}\text { Links to other data including photos, } \\
\text { Websites and related documents }\end{array}$ \\
\hline Coordinate information in UTM and latitude and longitude & \\
\hline
\end{tabular}

Integration of database with GIS applications are also common in geoheritage information management. One of the earlier work combining GIS application and the web was done by Ghiraldi et al., (2009) for the Piemonte Region, Italy. Here, they intergrated GIS applications with the internet to publish cartographical information which include images, descriptive cards and bird's-eye virtual views. This combination of Web-GIS application can perform as an instrument to present research results and to promote knowledge of geosites to the public at large. To reach to the general public, their Web-GIS application was developed using an open source web mapping known as MapServer (https://mapserver.org). Li et al., (2015) also discussed how GIS was used with the internet to form a WebGIS database for several databases in China. Another way of record keeping is using the GIS geodatabase found in ArcGIS application. The advantages of using GIS geodatabase were discussed in Cioban et al., (2011). The advantages that were 
highlighted are: geodatabase provides editable domain for attributes; a new geodatabase can be generated that has the same structure as the previous one and flies transfer are also achievable; sharing of common data among users is possible; and validation rules that control how features behave can be imposed in a geodatabase.

\section{(c) Public Involvement}

Due to the design structure of the internet, user plays both roles as information consumer and also as information provider; thus this dynamic system creates an environment where collaboration among individuals can be made (Flanagin \& Mertzger, 2008). An appropriate term for this 'interaction' is crowdsourcing. An example of crowdsourcing is where an organization is using a network of collaborators to solve a problem (Misra et al., 2014). Alternatively, crowdsourcing can be defined as a system that enlists a multitude of people to assist in solving varieties of issues (Doan et al., 2011). However useful the crowdsourcing approach is, the effectiveness of the system used to collect the information is dependent on the end-users, which is the public in general. Therefore, the level of knowledge in geospatial technology such as GIS skill of the end users must be taken into account for any construction of applications that are based on GIS (Aburizaiza \& Ames, 2009). In geographic terms, crowdsourcing is similar to volunteered geographic information (VGI). This is a term that denotes the collection of geographic information by way of crowdsourcing technique (Fast \& Rinner, 2014). Alternately, VGI can be defined as citizens contributing geospatial information about the earth or environment through a collaborative projects (Mooney et al., 2013).

Both systems use individuals who are not necessarily in the same organization to solve certain issues revolving around an organization. Although crowdsourcing or VGI is less labour-intensive and can minimize cost within an organisation, several precautions need to be taken attentively such as the quality, reliability and overall value of the data that were shared (Flanagin \& Metzger, 2008). One of the good examples of VGI is the information sharing in Wikimapia and Flickr sites where photographs are referenced with GPS coordinates and descriptions (Goodchild, 2007). Ho and Rajabifard (2010) described VGI as a spatial information product for the society by the society. An example of crowdsourcing approach implemented in geoheritage practices is the development list of geoheritage sites in Nova Scotia, which involved input from the public in general (Calder et al., 2017). Another example was discussed in Dahl et al., (2015). Due to absence of systematical classification and identification of important geosites in their database, crowdsourcing was used to validate and valorize registration that were conducted for the past 30 years. Guidelines however, were used for these validation practices. By getting the public involved, they hope to raise awareness on important sites.

Other example of full utilization of the usefulness of VGI was during the earthquake relief effort in Haiti. Zook et al., (2010) have perfectly demonstrated how a volunteer geographic information (VGI) system can contribute to a better interaction between distant places for relief work and aid agencies without being physically present in the affected locations. They also argued that crowdsourced information is likely to be just as helpful as information that were produced by centralized means in their relief works.

Other ways to get input from the public is by web-mapping using an open source applications, such as the google map. This method was used by Martin et al., (2014) to disseminate and obtain information on geosite inventories Switzerland at both national and regional scales. According to Martin et al. (2014), there are three components in webmapping, which are dynamism, usability, and interactivity. These components summarize the manners in ways web-mapping can be used:

a) Users can edit, update, replace and add items in real time; 
An Inventory Database for Geoeducational Outreach Based on Volunteered Geographic Information (VGI) Approach in Malaysia

b) No specialised training is required to handle tools in the web to present concise and clear in-formation;

c) Some thematic and spatial selections can be conducted easily by users.

In terms of devices for data sharing, smartphones are common tools to share geospatial information at the moment (Neis \& Zielstra, 2014). Senaratne et al., (2014) argue that due to the ubiquity of advancement in web and location-sensing technologies, over the pass decades, which some are handheld devices, spatial information can be produced easily regardless of the citizens' knowledge on geospatial. However, some of these information that were provided by the public have drawbacks because of their varying quality (Senaratne et al., 2014). According to them, this is due to the varying technologies and tools with different level of accuracy provided by diverse contributors and the lack of gatekeepers.

\section{(d) Getting the message across}

Keeping the geosite information in a database away from the public will not be beneficial for conservation and promotion efforts. Public education and awareness is very important in keeping the place well protected from destructive development. One of the excellent efforts by the management of Nova Scotia for geosite promotion is to allow user to download the locations of interesting geoheritage sites in a digital format (Calder et al., 2017). Apart from free downloadable data, a story map on the geoheritage of Nova Scotia was also produced for public awareness. The story map is complete with photos, maps, descriptions, and also provides link to other useful information about the sites. Both, information on geopark and its interpretation systems are necessary for geoeducation and geoconservation (Li et al., 2015). They also show that to be effective in communicating geoeducation to the public, a geopark must have at least two basic systems; a geopark database and a geopark website. An example of these systems are shown in the structure of the Ningcheng Geopark Database. The few important elements found in the database are information on fundamental geology, resources and environment and tourism information, and according to them devices such as smartphone can also be used to accelerate scientific information on geoparks for education and communication purposes.

\section{EMERGING TREND OF GEOGRAPHIC INFORMATION MANAGEMENT IN TOURISM}

In the past, GIS is primarily used by professionals in the administration mainly due to the fact that they had access to required peripherals for the system and they are the one to process and analyse spatial data (Abdalla \& Frank, 2014). Commonly in the previous years, maps and multimedia stored in CD-Rom are tools used in environmental tourism (Castaldini, 2008). Emerging of new technological trends such as big data, collective sensing, advanced spatio-temporal data, and internet of things can be used to address information needs in tourism activities (Steenbruggen, 2016). Based on the document published by the United Nations Initiative on Global Geospatial Information Management (UN-GGIM 2013), data captured and generated have grow exponentially and this trend will continue in the next five to ten years with the emerging of new technologies. This new trend owed it successes to the existence of 'mobile' technology (UN-GGIM, 2013; Abdalla \& Frank, 2014; Sttenburggen, 2016). Cayla \& Martin, (2018) envision that in the future, cutting edge technologies such as geovisualisation models using high-resolution images and 3 D representation techniques will be useful for such following events:

a) To prevent geohazard events;

b) To keep digital archive of vulnerable sites;

c) To produce replicas such as cave replicas; 
d) To augment reality for geotourist.

In light of this emerging technologies and how they will benefits geosites conservation, relevant agencies who are directly or indirectly involve in geosite management must use this technology to collect vast information from the public and at the same time to use these emerging technologies to educate people on matters concerning geosite conservation.

\section{METHODOLOGICAL FRAMEWORK}

Discussions on the methodology are divided into two parts, namely: the nontechnical requirement of the database and the database construction.

(a) Database Non-Technical Requirement

There are several requirements outlined when the design of the database was planned. The requirements are:

a) Crowdsourcing - The main aim of the system is to be able to collect data from everywhere and anyone.

b) Free - The system should be free or at a nominal cost. Maintenance cost, whenever possible should be avoided.

c) User friendly - Easily maneuvered, no hidden details or link.

d) Familiarity - The system must be tools that are commonly used by everyone. This is particularly applied to forms and maps that are displayed in the site. Apart from end users, the system should also be in a condition where it is easy to be maintain and managed by an appointed administrator.

e) File conversion - In terms of a file conversion, the raw data should be easily converted to other formats to be used in other software (e.g. GIS softwares).

f) Mobile friendly - Smartphone should be able to display the system for viewing and collecting data.

g) Public display - Public can view the proposed geosites in a map and also the attributes relevant to the geosites.

h) GIS software - GIS software should be able to store, display, and analyse the data from the system whenever needed.

\section{(b) Database Construction}

In general, the whole system can be divided into four stages (Figure 1): the collection, organizing and conversion of files, storage, and finally the display. At the collection part, users will enter the information on a particular geosite via the google form provided by the administrator and later, the administrator will organise the data entry into a systematic order. Conversion of files are only conducted when necessary, for example, if the data is needed in a different format or file extension. The third part is the storage, where there are several options on how the data can be kept, based on the decision of the administrator. The final part is the display, where the data entered by the user is shown to the public, which is under the discretion of the administrator.

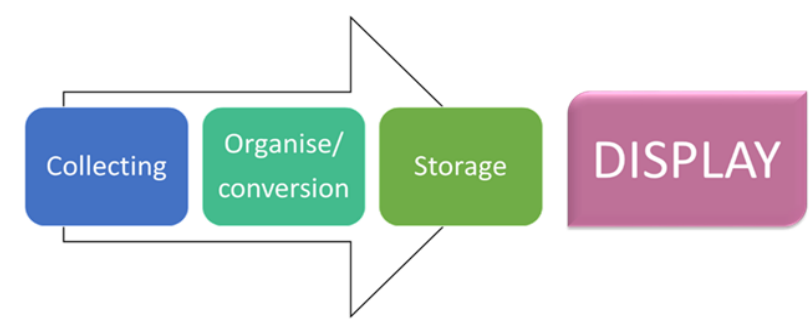

Figure 1. Stages in managing the database 
An Inventory Database for Geoeducational Outreach Based on Volunteered Geographic Information (VGI) Approach in Malaysia

These four parts of the database were produced by using several free online tools as presented in Table 2. Each of the four parts are discussed as follows:

Table 2 Free online tools that were used to construct the database

\begin{tabular}{|c|c|c|c|}
\hline \multicolumn{3}{|c|}{ Stages } \\
\hline Collecting & Organising/Conversion & Storage & Display \\
\hline Google form & Google sheets & Google drive & Wix.com \\
\hline & Microsoft Excel & Geodatabase & Google Maps \\
\hline & & & Google Earth \\
\hline & & & ArcGIS \\
\hline
\end{tabular}

\section{i) Collection Stage}

The collection stage involves users to enter information directly into the inventory form designed using the google form tool. The inventory form has three categories of questions that are considered crucial for a potential geosite, which are: General category, geosite characterization, and geosite management. Explanation on each of the categories is given in the result and discussion section of this article. The main domain of the form is a text. Pictures such as maps and photos can also be uploaded on the form. After users enter their data, the administrator will examine the data quality and he can either reject, accept or keep the data for future consideration based on the data quality. Subsequently, the location and basic information of the site will be displayed on a google map for the public. Figure 2 outlines the steps in the collection stage.

ii) Organisation and Data Conversion

This stage is controled by the appointed administrator who will conduct the labelling, organise the data into groups of locations (e.g. in the same state, district, etc) and also prepare the data in a file that can be easily converted to other file types. The tools involved in this stage are google sheet and Microsoft Excel.

\section{iii) Storage}

The data is stored in a google sheet and kept in a google drive. However, the administrator can also store the data in a geodatabase (ArcGIS). Microsoft Excel is another option to store the data, but since some of the data contain pictures or maps, Microsoft Excel might not be a proper option.

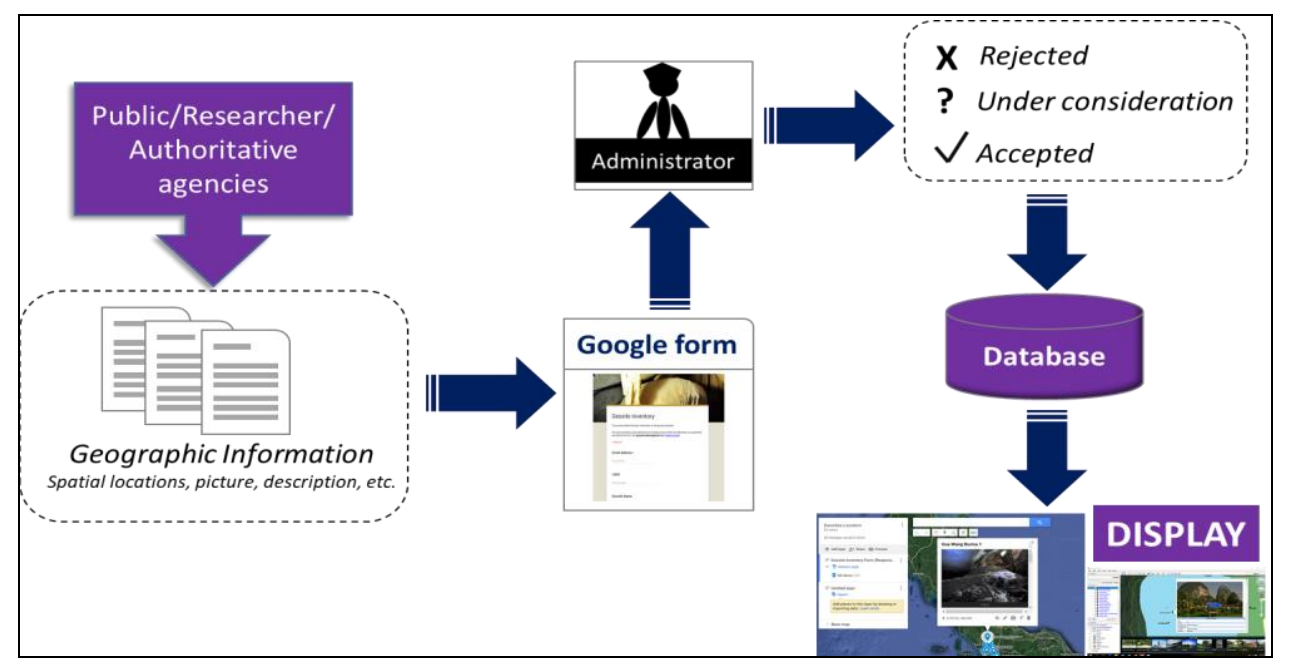

Figure 2. Stages in the collection parts of the database 


\section{iv) Display}

To display the information of geosites in Malaysia, the wix.com website builder is used to display maps and also to keep the inventory form. This tool is easy to use and a website can be created within days. Google maps and Google Earth are used to display the location of geosites and their information. ArcGIS can also be used to display the data when needed.

\section{RESULT \& DISCUSSION}

The discussions on the database are divided into four sections as follows: the main display, geo-educational sites, maps on potential geosites, and the inventory form.

\section{a) Main Display}

The database was created in a form of a website that is reachable via the link below: https://geoparkmalaysia.wixsite.com/geoparkmalaysia

The wix.com website builder was used to construct the main display. The database is linked to other important elements of the database including the inventory forms, geoeducational locations, and the potential geosites map. The display of the database is divided into four main sections as follows:

i) The title section that informs users about the aim of the geoheritage efforts in Malaysia (Figure 3)

ii) The link to the national and UNESCO Global Geoparks in Malaysia. So far, only the websites of the Langkawi UNESCO Global Geopark is active, the other two are still under construction

iii) Geoeducational locations of several places in Malaysia

iv) Potential geosites map and the inventory form

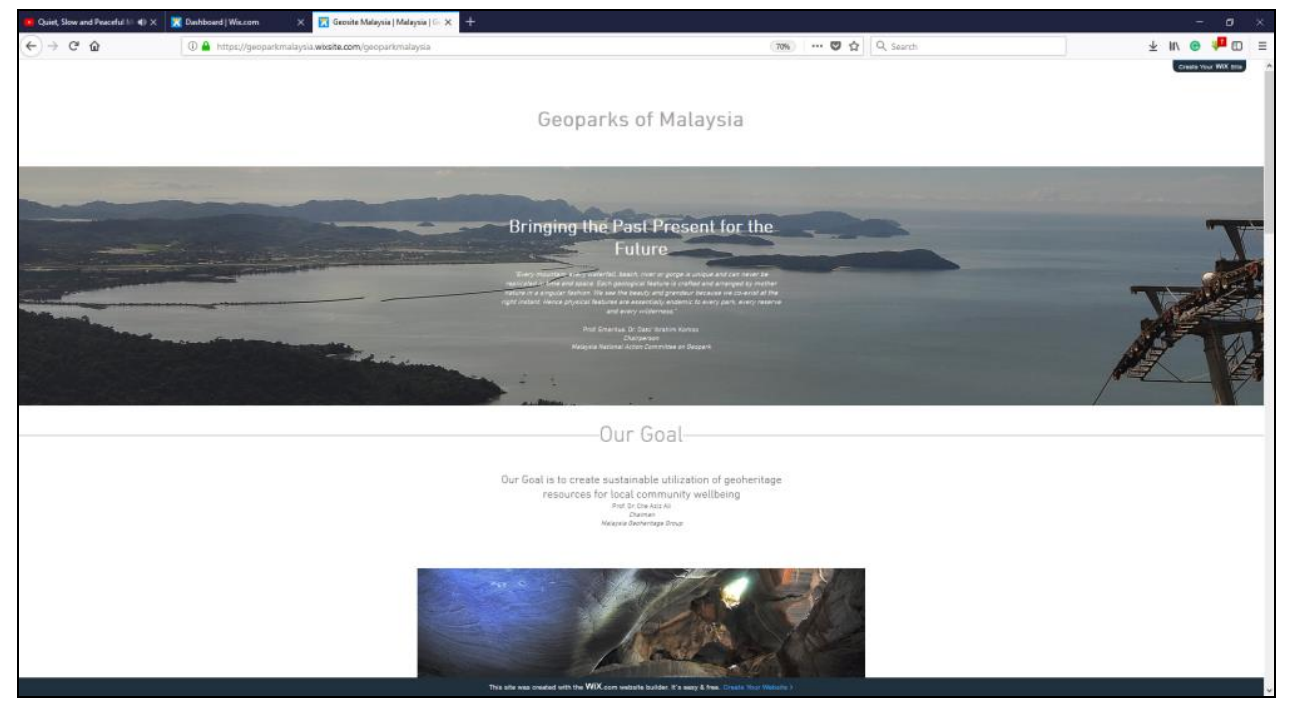

Figure 3. The aim of the geoheritage effort in Malaysia is firstly presented to inform user on the aim on the geoheritage conservation in Malaysia

\section{b) Geoeducational Sites}

One of the main aims of this database construction is an 'outreach' to wider audience on the awareness of geology in Malaysia. Digital technologies such as website and smartphone are notably indispensable tools to achieve this target (Li et al., 2015). Therefore, this database was constructed based on the VGI approach as a two way 
communication to ensure that this database is not only meant for inventory purposes, but also as an information portal on geosites in Malaysia for the end users. As for the geoeducational purpose, this database is linked to the geopark websites in Malaysia and also to some geo-educational sites that were created based on a story map approach (Figure 4). The authors hope that with the listing of these geoeducational sites, they can be part of environmental education activities to increase awareness among the public to protect nature (Ilies et al., 2017). Story maps are also known as geovisual stories which refer to data-driven story telling practices in journalism and geovisual analytics (Berendsen et al., 2018). Maps can be a powerful medium to convey a 'story' which in the past was perceived in oral or textual forms (Strachan \& Mitchell, 2014). One of the ways to entice people to read more on factual subjects is to construct a storyline. This study uses the story map approach by ESRI to construct a storyline depicting geological facts. Story map is a tool that is equipped with simple, non-technical interface and combined with dynamic web maps as well as other story elements that makes them an ideal technology for education (Strachan \& Mitchell, 2014). The ESRI story map tool is complete with satellite imagery which this study uses fully to create a map. Marta \& Osso, (2015) pointed out that map-based storytelling is a very useful tool to communicate knowledge focusing on 'where' the stories happened.

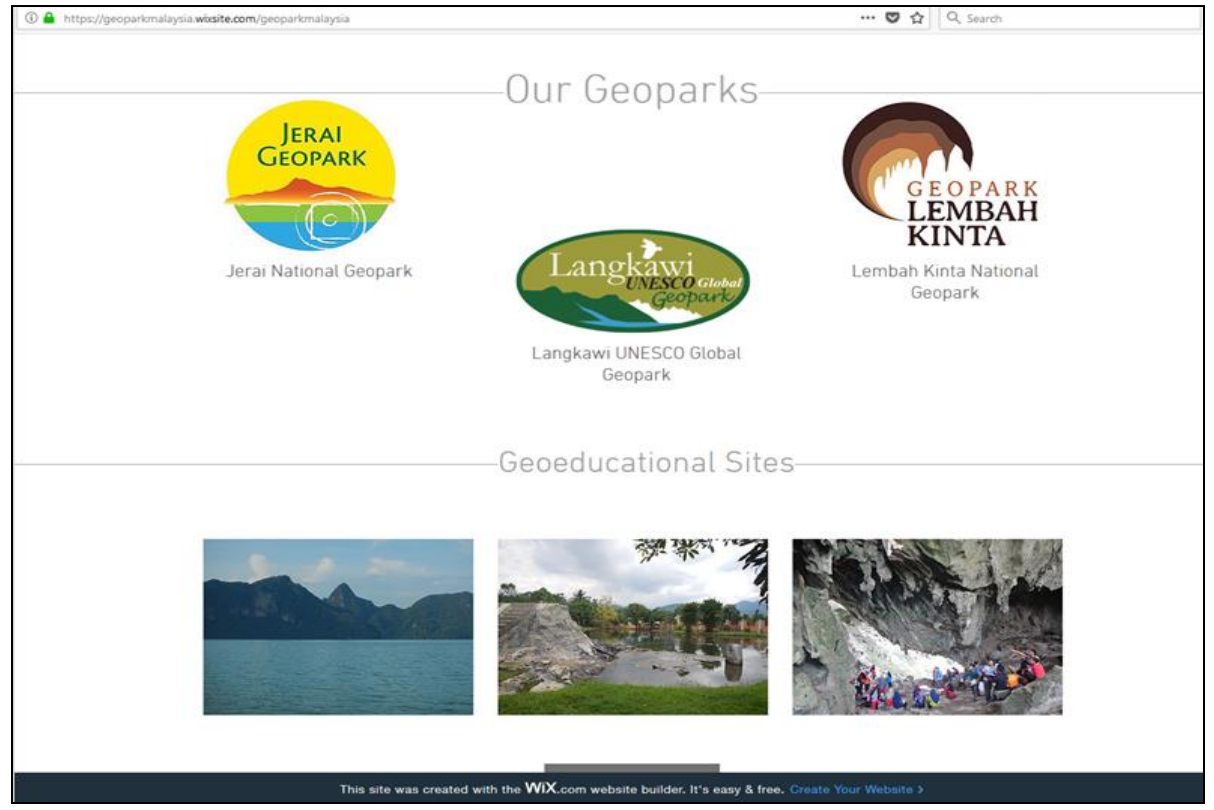

Figure 4. Links to other geoparks in Malaysia and also to some of the story maps that were constructed for public education

Therefore, story based on maps is very effective and easily implemented with GIS, web maps and mobile apps are now readily reachable to almost everyone. This study has designed two story maps in English for public education. A brief description for each story map is given as follows:

i) Through the Lens: Rocks under a Microscope

This story map showcases detail petrographic studies that were carried out to determine physical changes that occurred in a rock when in contact with igneous intrusion. Rocks were collected from different distance from the contact zone. The size, 
Norbert SIMON, Che Aziz ALI, Marilah SARMAN, Dana BADANG, Tanot UNJAH, Mat Niza RAHMAN

shape, type, and the appearance of minerals under the microscope were identified and the changes were recorded as rocks getting closer to the contact zone. In the story map, the name of minerals, shape, size, and appearance are stated (Figure 5).

ii) Geoheritage Evaluation of the Hulu Langat Geothermal Geosites, Selangor, Malaysia

The second story map portraying the different geothermal sites in the district of Hulu Langat, Selangor. Various information can be obtained from this story map such as the lithology, the location of the geothermal sites, and also other general information that are useful for visitors (Figure 6). This story map also provides some information on the main chemical elements in each of the geothermal sites.

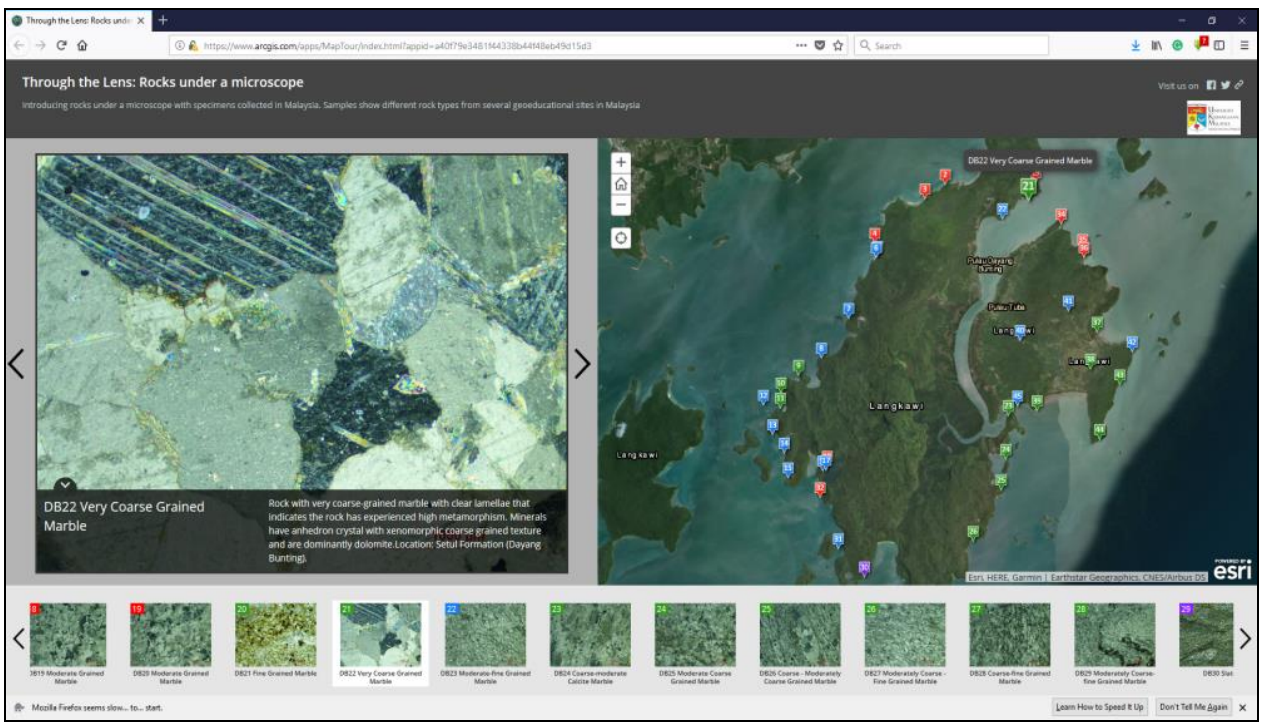

Figure 5. Besides geological information, this story map educates the public on rock features under a microscope

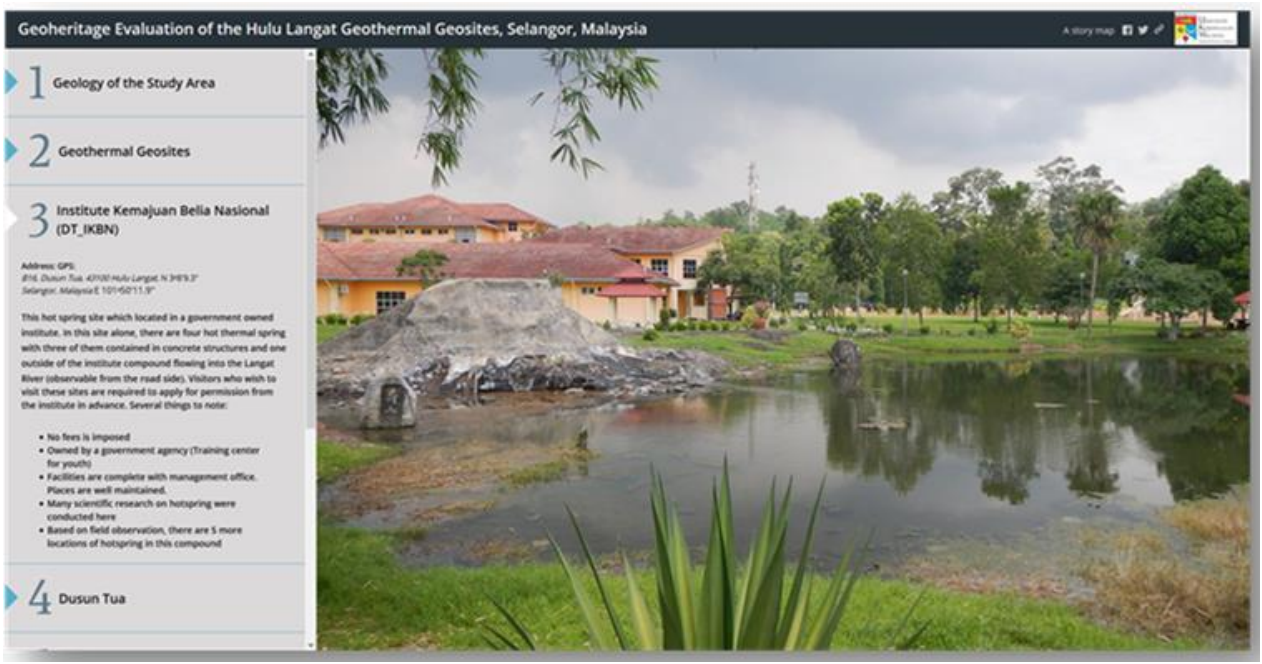

Figure 6. Information on geothermal sites portrayed in a story map (Source: background map based on ESRI 2017) 
An Inventory Database for Geoeducational Outreach Based on Volunteered Geographic Information (VGI) Approach in Malaysia

\section{c) Maps on Potential Geosites}

The study uses satellite imagery from Google Maps and Google Earth to show the locations of potential geosites around Malaysia. The locations so far only cover parts of the three states in Malaysia, namely, Kedah, Perlis and Perak. These maps provide an interactive environment for users of wider background which may lack of geospatial knowledge. Non-technical map for non-technical users are important for greater participation of communities in decision making process (Ellul et al., 2009).

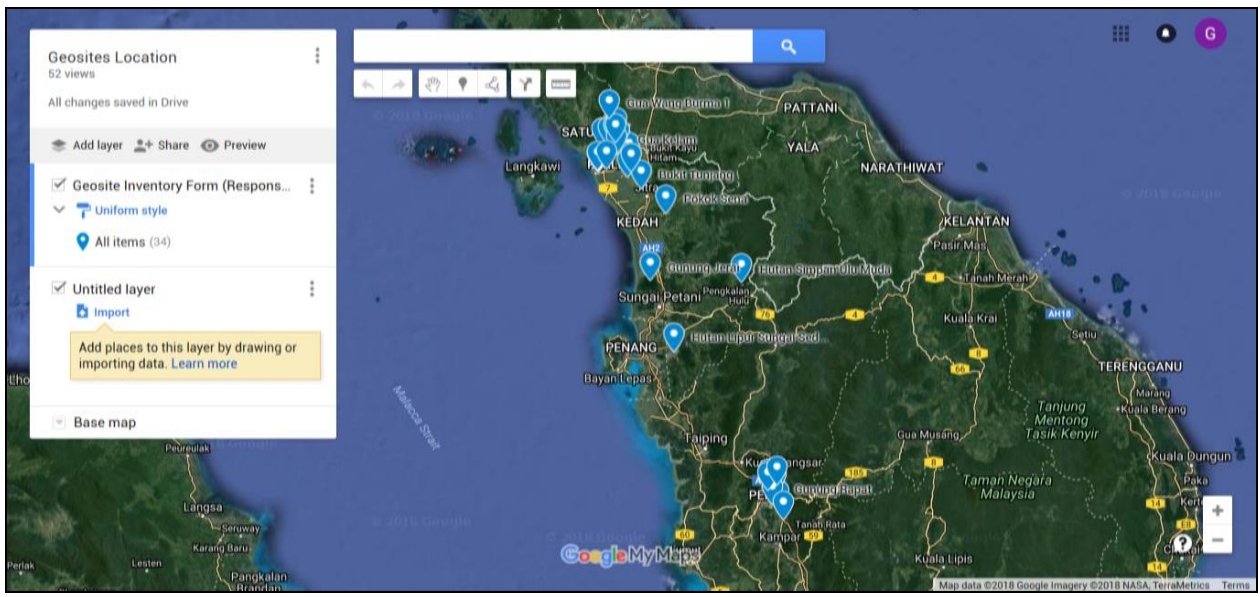

Figure 7. Some of the potential geosite locations as mapped on Google map (Source: background map based on Google Map 2018)

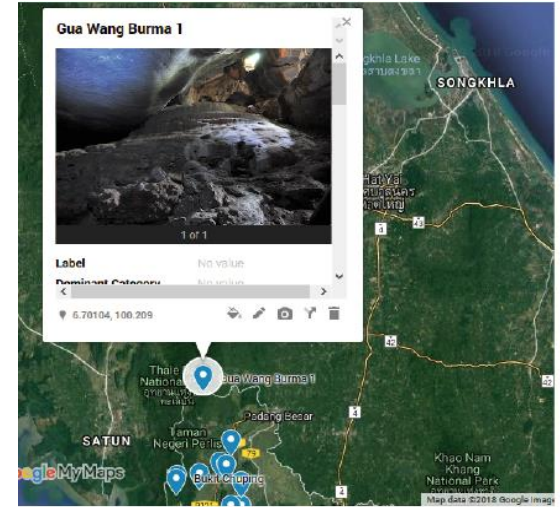

(a)

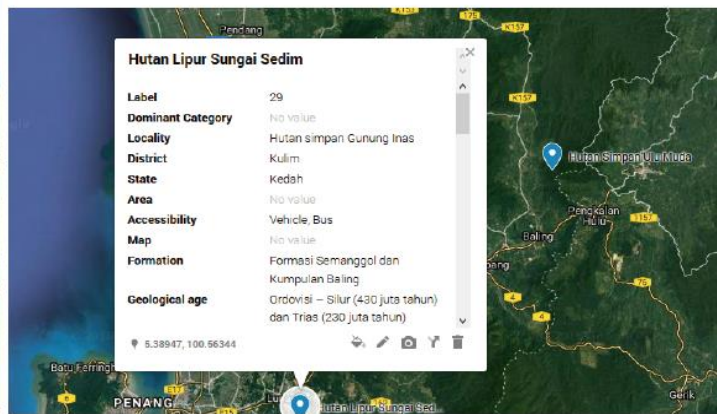

(b)

Figure 8. Useful functions in Google Map (a) Display pictures embedded together with the point location (b) Attributes of the locations can be displayed once a user clicks on any point locations (Source: background map based on Google Map 2018)

Google Maps and Google Earth are selected to display the locations because both of these tools are commonly used to find places, display maps, query and have numerous functions that are freely available to users. Figure 7 shows some of the potential geosite locations as mapped on the Google map and Figure 8 (a) and (b) displays some of the functions available in Google Map such as displaying picture and information when a user click on a point location. Apart from Google Map, this study also uses the capability of 
Google Earth to display information on potential geosites in the database (Figure $9 \mathrm{a} \& \mathrm{~b}$ ). Other than using the tools from the internet, this study also fully utilises the geodatabase (ArcGIS) capability to provide visual on the distribution of geosites in Malaysia.

\section{d) Inventory and Data Keeping}

As mentioned in the methodology section, there are three categories of question in the inventory form and each category has its own sub-questions (Table 3). The general category consists of questions that describe the potential geosite with regards to its locality, GPS location, area, and accessibility. Information required in the geosite characterization category are mostly geological in nature such as the name of the geological formation, detail explanation on the dominant geological category, the level of ranking, and uniqueness. Finally, the geosite management category covers issues on the current preservation status of the area, its level of vulnerability to damages, current functions, and legislative provision.

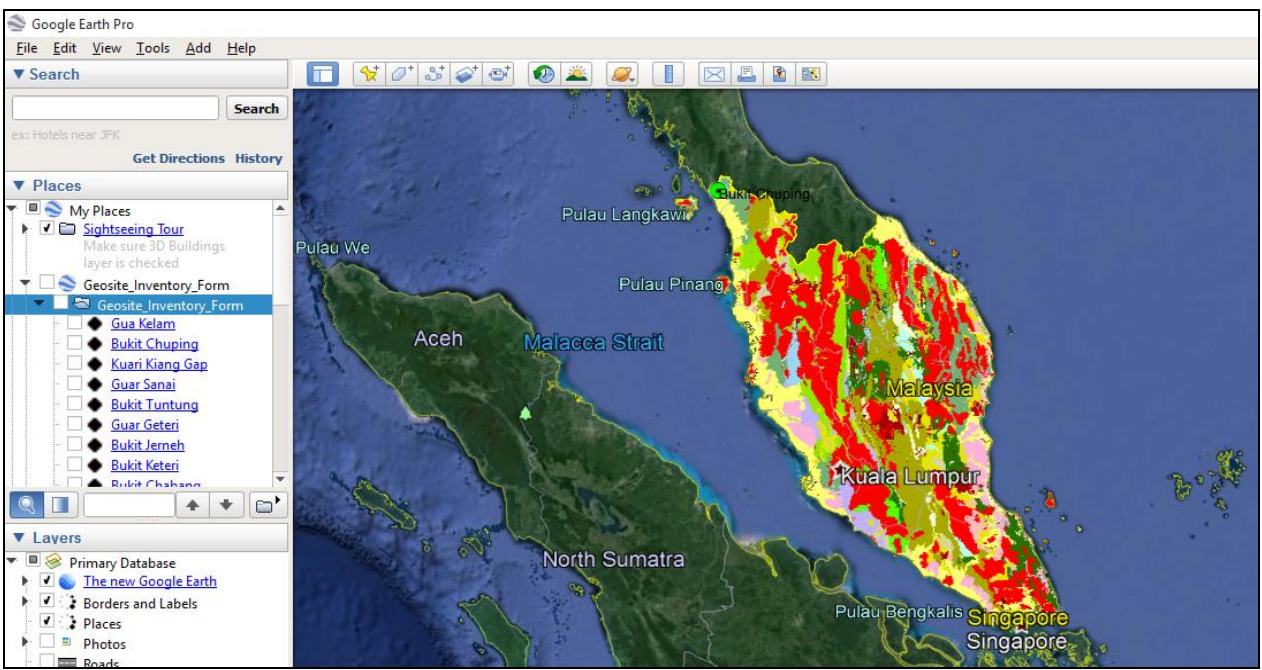

(a)

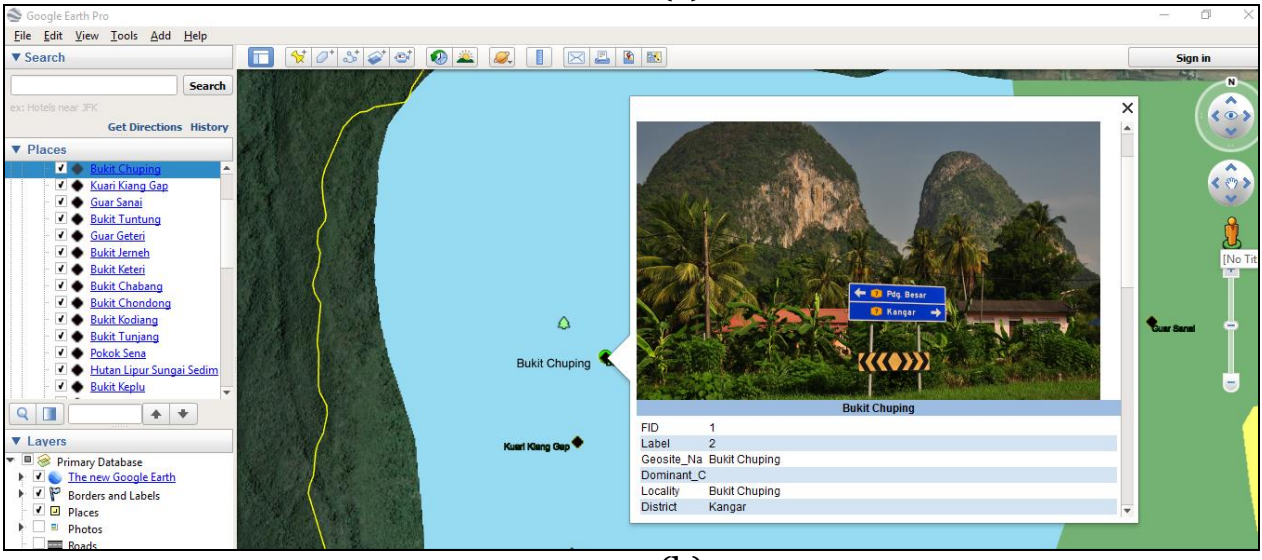

(b)

Figure 9. Some available functions that can be used to display maps that are useful for this study (a) Geological map embedded on Google Earth (b) Picture together with the information for a potential geosite appears when a user clicks on the point location of the potential geosite (Source: background map based on Google Earth Pro 2018 \& geological map from the Director General of Geological Survey of Malaysia 1985) 
An Inventory Database for Geoeducational Outreach Based on Volunteered Geographic Information (VGI) Approach in Malaysia

Table 3 Items in each category of the inventory form

\begin{tabular}{|c|c|c|}
\hline General Category & Geosite Characterization & Geosite Management \\
\hline 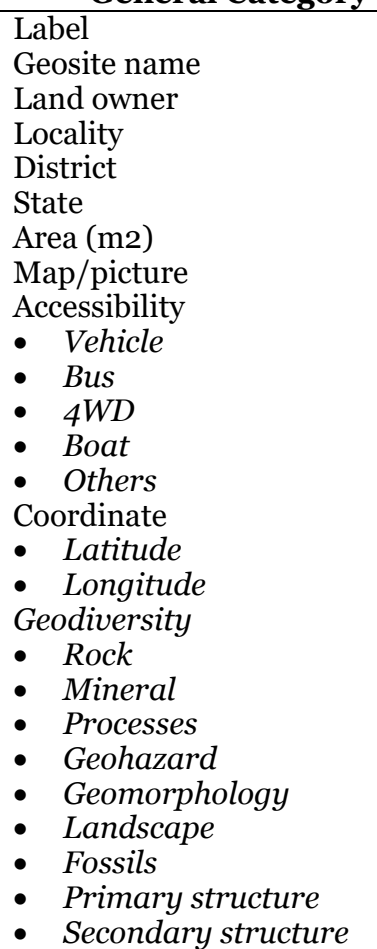 & $\begin{array}{l}\text { Formation } \\
\text { Geological age } \\
\text { Geoheritage value } \\
\text { (Explanation in detail) } \\
\text { - } \quad \text { Scientific value } \\
\text { - } \quad \text { Aesthetic value } \\
\text { - } \quad \text { Cultural value } \\
\text { Ranking } \\
\text { - Local } \\
\text { - National } \\
\text { Uniqueness } \\
\text { - } \quad \text { Unique } \\
\text { - Rare } \\
\text { Dominant geological feature/s } \\
\text { (Explanation in detail) } \\
\text { - Rock } \\
\text { - } \quad \text { Mineral } \\
\text { - } \quad \text { Geohazard } \\
\text { - } \quad \text { Geomorphology } \\
\text { - } \quad \text { Fossils } \\
\text { - } \quad \text { Primary structure } \\
\text { Secondary structure }\end{array}$ & $\begin{array}{l}\text { Current status of conservation } \\
\text { - } \quad \text { Not preserved } \\
\text { Currently function as } \\
\text { - } \quad \text { Cultural/religious site } \\
\text { - } \quad \text { Recreation } \\
\text { - } \quad \text { Education } \\
\text { - } \quad \text { Research } \\
\text { - Tourism site } \\
\text { - } \quad \text { Residential } \\
\text { - Others } \\
\text { Geoheritage level } \\
\text { - National } \\
\text { - } \quad \text { Global } \\
\text { Legislative provision } \\
\text { - None } \\
\text { - Vulnerable } \\
\text { - Highly vulnerable } \\
\text { - Details } \\
\text { References of geosite } \\
\text { Other remarks }\end{array}$ \\
\hline
\end{tabular}

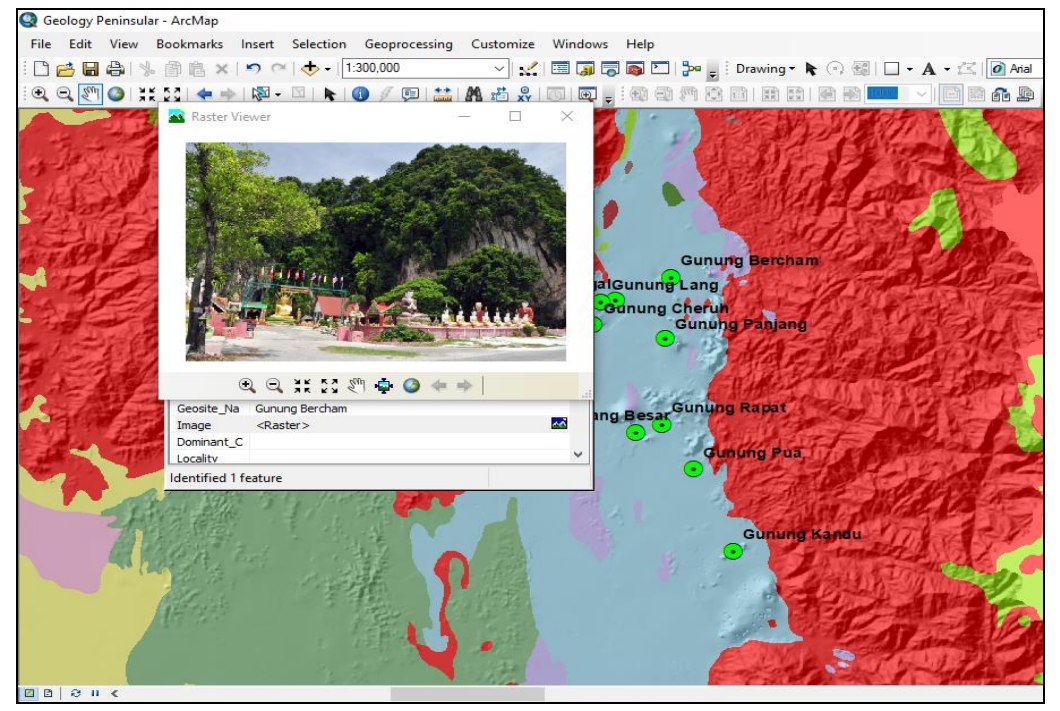

Figure 10. Visualisation of geosites distribution using geodatabase

(Source: Geological map from theDirector General of Geological Survey of Malaysia 1985)

A snapshot of the inventory form designed to collect information is presented in Figure 11. The data entered by users will be automatically recorded in a Google Sheet that 
is kept in the google drive. Each of the columns in the Google Sheet contain information for each of the questions asked in the inventory form (Figure 12).

Besides Google Sheet, geodatabase tool in ArcGIS software is also used to keep the data permanently. However, conversion is needed to enable the data from the Google Sheet to be usable in ArcGIS; this is done by converting the Google Sheet data to Microsoft Excel file and later to '.shp' extension. The geodatabase also has the capability to display data with picture and attributes of a site (Figure 10). The purpose of keeping the data in a geodatabase is for GIS analysis in the future.

\section{e) Administrator Responsibility}

The administrator is responsible to organise and manage the data entered by users. Data examination is done in a meeting with experts in the geoheritage field because some of the data might not have correct interpretation and also may contain errors due to different devices used to capture the information (Senaratne et al., 2014). Other reasons might be that the information entered is sensitive or disclosing the information is prohibited by law and copyright.

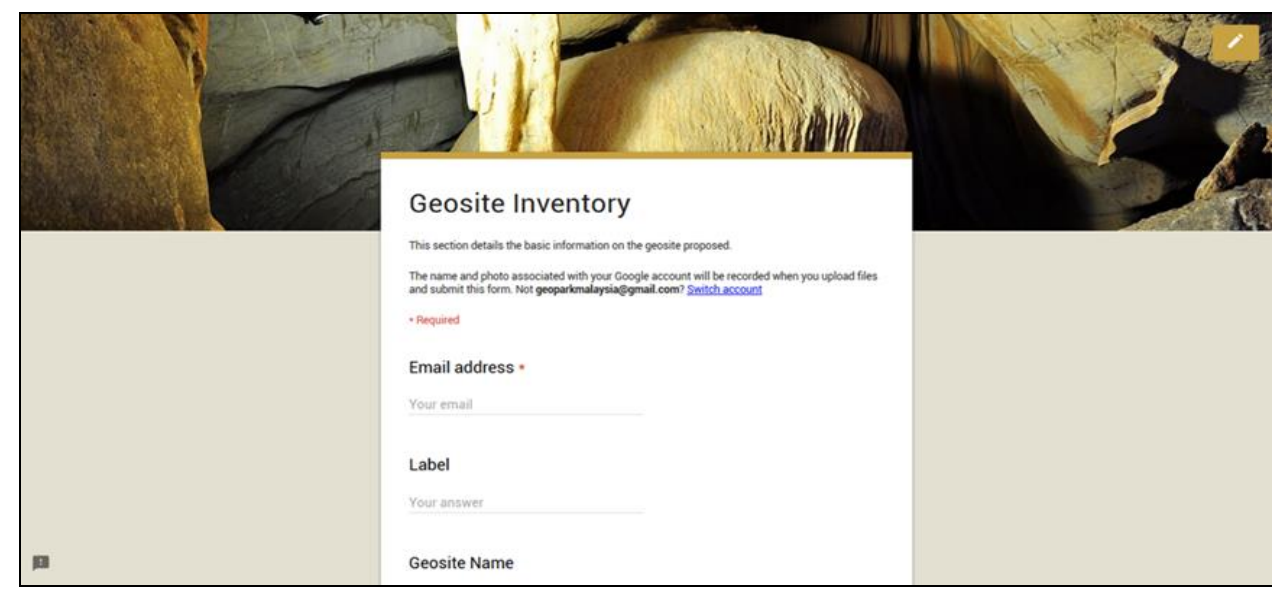

Fig. 11. The layout of the inventory form for data collection

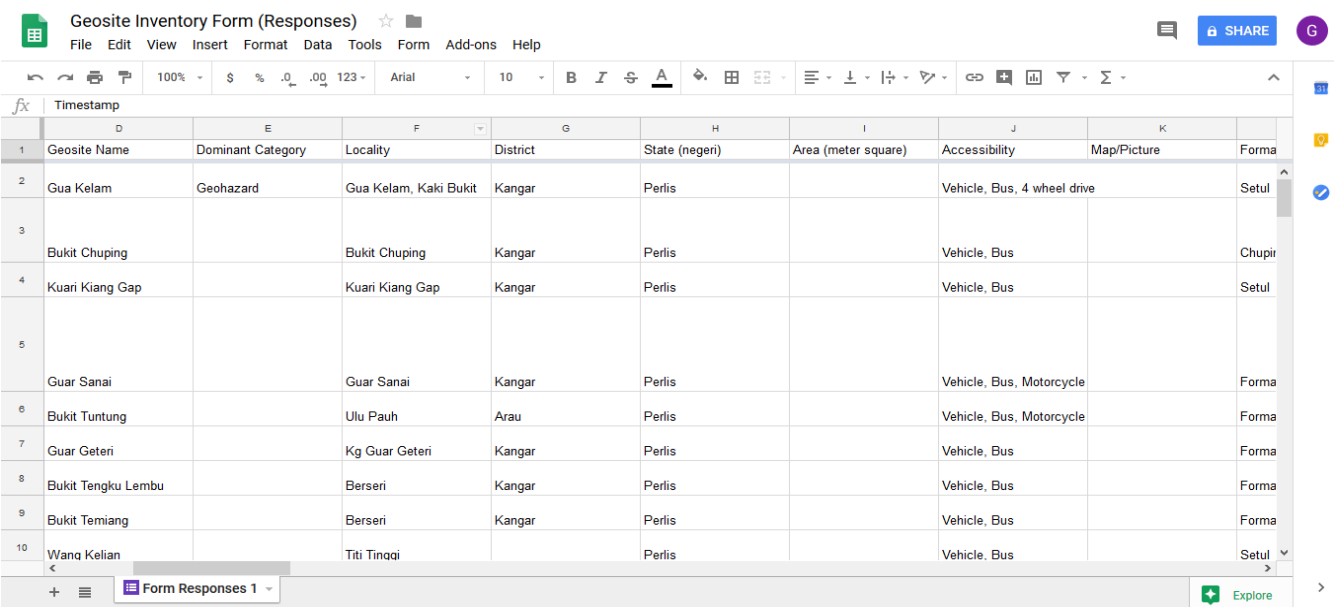

Figure 12 Data in a Google Sheet with each row representing a different location and each column represents a question given in Table 3 


\section{f) Smartphone Compatibility}

One of the requirements of this study when developing the database in a form of a website is to make sure that it can be displayed on a smartphone. This is because, smartphone can accelerate information sharing which is vital in geoeducation (Li et al., 2015). Figure 13 shows how the database is displayed on a smartphone.

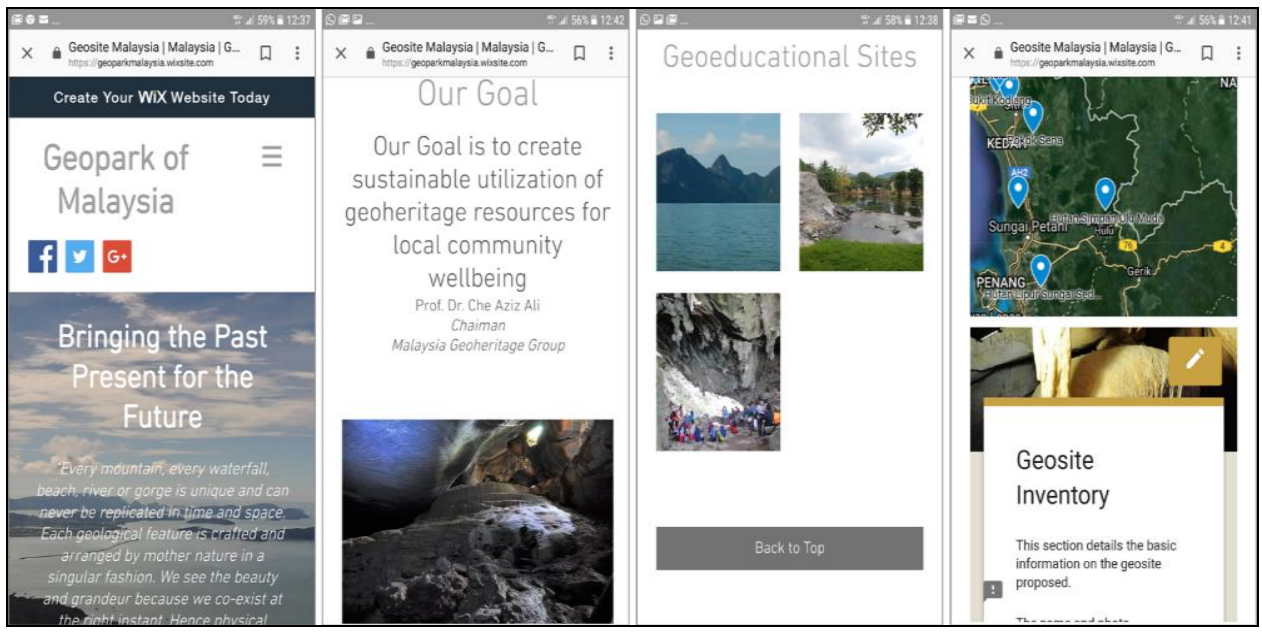

Figure 13. The database layout as displayed on a smartphone

\section{CONCLUSION}

The aim of this study to construct a database based on crowdsourcing and VGI approaches can be considered successful. The system was constructed successfully using different tools that are available online. These tools such as Google Form, Google Earth, Google Map, and Wix.com are free tools, thus, there is no cost involved in the construction of the database. The system was constructed with the objective that the user and the administrator of the database do not need intensive training to get familiar with the system. The database is now keeping around 45 potential geosites throughout three states: Perlis, Kedah, and Perak. Certainly, there will be more data to be added in the future. For the geoeducation purpose, the story maps tool was used to create a webmapping storyline for two potential geosites in Malaysia.

The story map tool was used because it is user friendly, easy to scroll, clear in terms of presentation and description, equipped with a map, and interestingly designed to entice the public to learn more about geology. Overall, the database system produced in this study is satisfactory and can be browsed using both computers and smartphones.

\section{Acknowledgement}

This study would like to acknowledge the funding provided by the Universiti Kebangsaan Malaysia, under the university research grant GUP-2017-83.

\section{REFERENCES}

Ali, C.A., Mohamed, K.R., Leman, M.S., Komoo, I., \& Unjah, T., (2012). Langkawi Geopark Geosites. Bangi: Institute for Environment and Development UKM (LESTARI).

Aburizaiza, A.O. \& Ames, D.P., (2009). GIS-enabled desktop software development paradigms, 2009 International Conference on Advanced Geographic Information Systems \& Web Services (GEOWS), pp. 75-79. DOI 10.1109/GEOWS.2009.28. 
Abdalla, A., \& Frank, A.U., (2011). Personal Geographic Information Management. In: Proceedings of the Workshop on Cognitive Engineering for Mobile GIS, Belfast, USA. CEUR Workshop Proceedings.

Berendsen, M.E., Hamerlinck, J.D., \& Webster, G.R., (2018). Digital Story Mapping to Advance Educational Atlas Design and Enable Student Engagement. International Journal of Geo-information, 7 (125): 123. doi:10.3390/ijgi7030125.

Betard, F., Piraud, A., Dandurand, G., Viette, P., \& Kuhnel, A., (2015). Multifinality in geoheritage inventories: a cross-cutting approach of geotourism and geoconservation issues in the "Causses du Quercy" Regional Natural Park (Lot, SW France). International Congress "Geoheritage Inventories: Challenges, Achievements and Perspectives”, Toulouse; https://hal.archives-ouvertes.fr/hal-01231708; International Congress "Geoheritage Inventories: Challenges, Achievements and Perspectives", Toulouse, Sep 2015, Toulouse, France. 2015.

Brilha, J., (2016). Inventory and Quantitative Assessment of Geosites and Geodiversity Sites: a Review. Geoheritage, 8: 119-134.

Brocx, M. \& Semeniuk, V., (2009). Developing a tool-kit for geoheritage and geoconservation in Western Australia. In Brilha, J. \& Wimbledon, B. (Eds). ProGeo News, 1. http://www.progeo.se. 3oth May 2018 (online).

Calder, J. H., Poole, J. C. \& Cowper, S. L., (2017): In Geoscience and Mines Branch, Report of Activities 201617; Nova Scotia Department of Natural Resources, Report ME 2017-001, p. 13-15.

Castaldini, D., (2008). Maps and multimedial tool for the environmental tourism in protected areas of the Modena Appenines (Northern Italy). Geojournal of Tourism and Geosites, 1 (1): 13-33.

Cayla. N. \& Martin, S., (2018). Chapter 16 - Digital Geovisualisation Technologies Applied to Geoheritage Management. Geoheritage Assessment, Protection, and Management. Pages 289-303. Publisher: Elsevier.

Cioban, A., Matei, F., Pop, I., \& Rotaru, A., (2011). The Importance of Geodatabases in a Geographical Information System. Bulletin UASVM Horticulture, 68, 2, 296-300.

Dahl, R., Bergengren, \& Heldal, T., (2015). A proposed new framework for valorization of geoheritage in Norway. Geophysical Research Abstracts, Vol. 17, EGU2015-14135, EGU General Assembly 2015.

Daud, M.S., Ismail, B. \& Leman, M.S. (2017). Geological Sites of Kinta Valley National Geopark. Ipoh: Minerals and Geoscience Department Malaysia (in Malay).

Diaz-Martinez, E. \& Gullen-Mondejar, F., (2009). A major achievement towards Geoconservation. In Brilha, J. \& Wimbledon, B. (Eds). ProGeo News, 1. http://www.progeo.se. 3oth May 2018 (online).

Dingwall, P., Weighell, T., \& Badman, T., (2005). Geological World Heritage: A Global Framework: Gland: IUCN. 52 pp.

Director General of Geological Survey of Malaysia., (1985). Geological Map of Peninsular Malaysia (1:50o,00o), 8th Edition, Minerals and Geoscience Department of Malaysia.

Dixon, G., (1996). Geoconservation: an international review and strategy for Tasmania. Miscellaneous Report, Parks \& Wildlife Service, Tasmania, 101pp.

Doan, A., R. Ramakrishnan, \& Halevy, A. Y., (2011). Crowdsouring Systems on the World-Wide Web. Communications of the ACM, 54 (4): 86-96.

Ellul, C., Haklay, M., Francis, L., \& Rahemtulla, H., (2009). A mechanism to create community maps for nontechnical users. International Conference on Advanced Geographic Information Systems \& Web Services, pp: 129-134. DOI 10.1109/GEOWS.2009.20.

Fast, V. \& Rinner, C., (2014). A Systems Perspective on Volunteered Geographic Information. ISPRS International Journal of Geo-Information, 3: 1278-1292.

Flanagin, A.J., \& Metzger, M.J., (2009). The credibility of volunteered geographic information. GeoJournal, 72: 137-148.

Ghiraldi, L., Coratza, P., De Biaggi, E., Giardino, M., Marchetti, M., \& Perotti, L., (20o9). Development and usage of Geosites: new results from research and conservation activities in the Piemonte Region (Italy). Studia Universitatis Babeş-Bolyai, Geologia, 54 (2): $23-26$.

Goodchild, M. F., (2007). Citizens as sensors: The world of volunteered geography. GeoJournal, 69: $211-221$.

Ho, S., \& A. Rajabifard., (2010). Learning from the Crowd: The Role of Volunteered Geographic Information in Realising a Spatially Enabled Society. In GSDI 12 World Conference: Realising Spatially Enabled Societies. Singapore, October 19-22. http://repository.unimelb.edu.au/10187/9214.

Kepalaitè, I., (2015(. The Importance of Geoheritage and Geotop of the Charts in Environmental Studies. Environment Technology Resources, 2: 133-136.

Komoo, I., Lim, C.S., Unjah, T., Sarman, M., \& Ismail, S., (2004). Geological heritage of Malaysian database for conservation and sustainable use. Geological Heritage of Malaysia - Theory and assessment geoheritage framework. Leman, M.S. \& Komoo, I. (eds). Bangi: LESTARI.

Ilies, D. C., Baias, S., Buhas, R., Ilies, A., Herman, G.V., Gaceu, O., Dumbrava, R., Maduta, F.M., (2017). Environmental education in protected areas, case study from Bihor County, Romania. Geojournal of Tourism and Geosites, 19 (1): 126-132.

Lazzari, M. \& Aloia, A., (2014). Geoparks, geoheritage, and geotourism: opportunities and tools in sustainable development of the territory. Geojournal of Tourism and Geosites, 13 (1): 8-9. 
An Inventory Database for Geoeducational Outreach Based on Volunteered Geographic Information (VGI) Approach in Malaysia

Li, Q., Tian, M., Li, X., Shi, Y., \& Zhou, X., (2015). Toward smartphone applications for geoparks information and interpretation systems in China. Open Geoscience, 1: 663-677.

Joyce, E.B., (2010). Australia's Geoheritage: History of Study, A New Inventory of Geosites and Applications to Geotourism and Geoparks. Geoheritage. DOI 10.1007/s12371-010-0011-z.

Martin, S., Reynard, E., Ondicol, R.P., \& Ghiraldi, L., (2014). Multi-scale Web Mapping for Geoheritage Visualisation and Promotion. Geoheritage, DOI: 10.1007/s12371-014-0102-3.

Ministry of Tourism, Arts, and Culture Malaysia. http://www.motac.gov.my/en/profile/policy, Access 07.08.2018.

Misra.A., Gooze, A., Watkins, K., Asad, M., \& Le Dantec, C.A., (2014). Transportation Research Record. Journal of the Transportation Research Board, No. 2414, Transportation Research Board of the National Academies, Washington, D.C., 2014, pp. 1-8. DOI: 10.3141/2414-01.

Mooney, Peter \& Corcoran, Padraig \& Ciepluch, Blazej., (2013). The Potential for Using Volunteered Geographic Information in Pervasive Health Computing Applications. Journal of Ambient Intelligence and Humanized Computing, 4. 10.1007/s12652-012-0149-4.

Mosbah, A. \& Saleh, A.A.K.M., (2014). A review of tourism development in Malaysia. European Journal of Business and Management, 6 (5): 1-9.

Moura, P., M., Garcia, M.D.G., Brilha, J.B., \& Amaral, W.S., (2017). Conservation of geosites as a tool to protect geoheritage: the inventory of Ceará Central Domain, Borborema Province - NE/Brazil. Annals of the Brazilian Academy of Sciences, 89(4): 2625-2645.

Neil, P. \& Zielstra, D., (2014). Recent Developments and Future Trends in Volunteered Geographic Information Research: The Case of OpenStreetMap. Future Internet, 6, 76-106; doi:10.3390/fi6o10076.

ProGeo, (2011). Conserving our shared geoheritage - a protocol on geoconservation principles, sustainable site use, management, fieldwork, fossil and mineral collecting. www.progeo.ngo/downloads/progeo_protocol_definitions.pdf, accessed 06.08.2018.

Randrianaly, H, N., Di Cencio, A., Rajaonarivo, A., \& Raharimahefa, T., (2016). A Proposed Geoheritage Inventory System: Case Study of Isalo National Park, Madagascar. Journal of Geoscience and Environment Protection, 4: 163-172.

Senaratne, H., Mobasheri, A., Ali, A.L., Capineri, C., \& Haklay, M., (2017). A review of volunteered geographic information quality assessment methods. International Journal of Geographical Information Science, 31 (1): 139-167. https://dx.doi.org/10.1080/13658816.2016.1189556.

Steenbruggen, J., (2016). Tourism Geography: Emerging Trends and Initiatives to Support Tourism in Morocco. Journal of Tourism \& Hospitality, 5 (3): 1-16.

Strachan, C. \& Mitchell, J., (2014). Teachers' Perceptions of Esri Story Maps as Effective Teaching Tools. Review of International Geographical Education Online (CRIGEO, 4 (3): 195-220.

Vye, E., (2016). Geoheritage of the Keweenaw Peninsula. Open Access Dissertation, Michigan Technological University. http://digitalcommons.mtu.edu/etdr/301.

Zakaraya, S.Z. (2017). Jerai Geopark to be recognized as National Geopark (National news in Malays). http://www.sinarharian.com.my/edisi/utara/sasar-geopark-jerai-diiktiraf-geopark-kebangsaan1.643108, accessed 07.08.2018.

Zook, M., Graham, M., Shelton, T., \& Gorman, S., (2010). Volunteered Geographic Information and Crowdsourcing Disaster Relief: A Case Study of the Haitian Earthquake. World Medical \& Health Policy Vol. 2: Iss. 2, Article 2. DOI: 10.2202/1948-4682.1069 pp. 1-33.

*** ESRI, (2017). Earthstar Geographics, CNES/Airbus DS | Esri, HERE. Garmin. https://www.arcgis.com/apps /MapTour/index.html?appid=a4of79e3481f44338b44f48eb49d15d3, accessed 17.12.2017.

*** Google Earth Pro, (2018). Google Earth Pro V 7.3.2.5491 (64-bit). Image Landsat/Copernicus Data SIO, NOAA, U.S. Navy, NGA, GEBCO, 15.01.2018.

*** Google Map, (2018). https://www.google.com/maps/d/u/2/edit?mid=1Pa4JWhW_npqx3nZWmECAB$\mathrm{X}_{5}$ OtRxRcWB\&ll=5.735066127137915\%2C101.06016674804687\&z=9, accessed 31.01.2018.

*** IUGS, (2012). Geoheritage Task Group Annual Report 2012. http://iugs.org/uploads/2012\%20GTG\%20 Report.pdf. 1st of June 2018 (online).

*** IUGS, (2014). Geoheritage Task Group Annual Report 2014. http://iugs.org/uploads/GH\%202014.pdf. 1st of June 2018 (online).

*** UN-GGIM, (2018). Future trends in geospatial information management: the five to ten year vision. Draft for Second High-Level Forum on GGIM, Qatar, $40 \mathrm{pp}$.

https://mapserver.org/, accessed 08.08.2018.

Submitted:

27.06.2017
Revised:

07.10.2018
Accepted and published online 10.10.2018 